Beata Piecychna

10.15290/cr.2017.18.3.02

University of Białystok

\title{
On the Hermeneutic Ontology of Language in Alice's Adventures in Wonderland and its Latest Polish Retranslation ${ }^{1}$
}

\begin{abstract}
In 2015, the latest retranslation of Alice's Adventures in Wonderland, produced by Grzegorz Wasowski, appeared on the Polish book market. As the translator explained in his afterword (Wasowski 2015: 159-173), the main aim of producing a new translation was to render the idea of the source text and to avoid word-for-word translation. Wasowski intended to render the so-called 'English spirit' contained within the original version by means of the richness of the Polish language. And although Wasowski accentuated the necessity for adapting a language to the wealth of human imagination, at the same time he claimed that the whole process must be completed moderately, within particular linguistic bounds. The main objective of this paper is to analyse whether the latest retranslation of Alice's Adventures in Wonderland meets the fundamental requirements specified by its translator, that is, whether the version renders the 'spirit' of the source text and whether the attempts which have been made might be referred to as moderate. The facets and dimensions of language depicted by Lewis Carroll are illustrated as juxtaposed against Hans-Georg Gadamer's ontology of language. Finally, the idea of so-called ontological parallelism is put forward, which stands for another type of equivalence, a key notion in the theory of translation.
\end{abstract}

Key words: retranslation, Alice's Adventures in Wonderland, Lewis Carroll, Grzegorz Wasowski, hermeneutics, Hans-Georg Gadamer's ontology of language.

\section{Introduction}

Alice's Adventures in Wonderland belongs to the so-called translation series. In the Polish context, the process of retranslation of the work started in 1910. The first translation, published by Wydawnictwo M. Arcta, located in Warsaw, and entitled Przygody Alinki w Krainie Cudów, was produced by Adela S. ${ }^{2}$ Since then, more than ten different translations have appeared, a figure that is all the more impressive since translations were completed by famous Polish novelists, poets or

1 I wish to express my immense gratitude to the reviewers of this paper for the valuable comments on the article.

2 The surname of the translator is unknown. 
translation theorists, for example, by Antoni Marianowicz, Maciej Słomczyński, Jolanta Kozak, and Elżbieta Tabakowska, to mention just a few. Also, investigating the ways in which Alice's Adventures in Wonderland was translated over time, in terms of proper names, domestication and foreignisation strategies, equivalence, etc., is a continuing concern within the field of Translation Studies.

Regardless of whether the emphasis is placed on the so-called passive or active retranslations (see Pym 1998: 82-83), they always pose significant challenges to the translation profession. These challenges can be seen on many levels: linguistic, pragmatic, cultural and social. The question arises, however, of what the motives behind the decision to retranslate a given text are. As Venuti (2013: 104) rightly suggests, retranslations are to challenge a previous version of the source text, as well as "to signify and call attention to their competing interpretation." Nevertheless, it is also often the case that retranslations are produced with the aim of addressing a different readership or even of creating a new one, of responding to certain social changes or to the changes of translational norms, as well as of modernizing the language which was used in previous target versions, particularly with regard to fiction which still enchants both younger and older readers.

One of the reasons why Alice's Adventures in Wonderland has gained so much popularity among not only readers but also translators is its deliberate entanglement in language. By employing parody, neologisms, puns and word plays, Lewis Carroll explored nonsense and used language as the basis for play with standard ways of communicating, as well as drawing readers' attention to the possibility of breaking the rules of language and, indirectly, to a lack of sense in conventions typical of everyday speech. More significantly, Carroll's linguistic intuitions found their ways into what linguists and philosophers of language ruminated about in the $20^{\text {th }}$ century.

Lewis Carroll's publication proved a great success not only in England but also in many countries across the globe; it has to be noted that the book has been translated into more than forty languages. As Zoe Jaques and Eugene Giddens (2016) note, Lewis Carroll was quite confident that the novel had a market abroad. The first two translations (into German and then into French), published by Macmillan, appeared in 1869. It is worth remembering that it was Carroll himself who decided that the book be translated into French by Henri Bué and into German by Antonie Zimmermann. At the same time, however, the author was perfectly aware of the fact that Alice's Adventures in Wonderland proved to be, at least to some extent, untranslatable, especially with relation to the rendition of puns, word plays and whole poems (Collingwood 2008: 136). As well as being cognizant of its untranslatability, Carroll devoted considerable attention to the readership of the renditions of his work:

For Carroll, child readers remained central to the act of translation, and both the acknowledgments for the German and French editions include a reference to the substitution of parodies of English childhood poetry for those that would be specifically intelligible to a child reader from another nation. Thus, for example, in the French edition Bué substitutes a parody of Fontaine's fable of 'Le Corbeau et le Renard' in place of Carroll's rewriting of Issac Watt's 'Against Idleness and Mischief'. Whilst the politics of the originals are rather different, both are clearly moralistic and are intended to teach a child lessons, and 
thus their parodies provide a playful inversion in keeping with Carroll's primary interest in Wonderland. (Jaques, Giddens 2016: 111).

Nevertheless, it was not only the textual dimension that became Carroll's focus of attention. While the author successfully managed to choose his preferred translators for Alice's Adventures in Wonderland, he also carefully scrutinized the manufacturing processes, regularly checking and verifying the formatting of the translated editions, the quality of paper, size of the book, etc. (Jacques, Giddens 2016: 109).

By employing a team of other writers and editors, Carroll intended to ensure that the translations into German and French were as accurate and idiomatic as possible:

\footnotetext{
Carroll here strongly wished to mark the production of these editions with his stamp of quality, evaluating the proof copies according to his own high standards. But when it came to analysing the standard of the textual translation itself, he had to call upon a wider team. Clearly, having handed over the act of translating his text to other writers - a necessary undertaking but one, like the employing of an artist for the English publication, which was not without issue for a protective author - Carroll was keen to be assured of the quality of the work. Although he had received the first full proof-translation of Wonderland from Bué by June of 1867 , Carroll took pains to circulate copies among various friends, colleagues ... (Jaques, Giddens 2016: 109-110).
}

For Carroll, the selection of a competent translator appeared to become equally important. The author even wrote to the House of Macmillan and requested assistance in finding "a man fit to try it", someone "who had written something of the sort, so as to have some sort of sympathy with the style" (Cohen and Gandolfo 1987:50). Hence, in the following sections of this paper, our attention will be focused on stylistic manifestations of the philosophical structure of language in the source and target texts.

Although the retranslations of the well-known fantasy work have received considerable critical attention both in Poland and abroad, most studies have only been carried out in a small number of areas, for example, in terms of the ways in which puns or word plays have been rendered by individual translators or in relation to the possible impact of a given translation on its readership. On the basis of the criteria which are often not well-established most of the studies conducted have been mostly restricted to limited comparisons of the source and target texts. Such expositions are unsatisfactory because in the majority of cases their authors did not take into account the necessity for conducting a detailed analysis of the source text in terms of genre, style, narration, or the relationship between the world of the narrative and general knowledge about the world existing outside the field of a literary work. More significantly, no single study exists which examines thoroughly the role of language performed in the work under investigation by applying a 'translation perspective'. Furthermore, the generalisability of much published research on the retranslations of the work is problematic, mostly due to the fact that the authors of such studies clearly have 
not paid close attention to the role of both linguistic and extralinguistic factors in the creation of the work in question.

In 2015, the newest retranslation, produced by Grzegorz Wasowski, appeared on the Polish book market. As the translator explained in his afterword (Wasowski 2015: 159-173), the main aim of producing a new translation was to render the idea of the source text and to avoid word-for-word translation. Wasowski intended to render the so-called 'English spirit' and multi-genre of humour contained within the original version by means of the richness of the Polish language. The translator is a craftsman, according to Wasowski; however, as he underlined, it is advisable that he/she becomes the co-author of a given work, in particular while translating children's literature. And although Wasowski accentuated the necessity for adapting a language to the wealth of human imagination, at the same time he claimed that the whole process must be completed moderately ${ }^{3}$, with some sort of restraint on the part of the translator. He also emphasized (2015: 161) that his purpose was neither to compete with Lewis Carroll nor to give vent to immense pride in one's actions. Furthermore, the aim of the 'unfaithful translation'-as the translator put it-was not to make an attempt to impersonate Carroll, an action resulting from inability to create a new work, because, as Wasowski underlined, it is much better to be a brilliant translator than a poor author (ibid). Crucially, however, it is important that a translator constantly controls himself/herself so that he/ she does not perform a prominent role, which an author deserves, according to Wasowski (ibid).

Jolanta Kozak (2000: 167) rightly highlights the need for diagnosing the source text before the analysis of the target text can be attempted. According to the author, if the diagnosis is right, only then is a researcher able to determine the translation problems which the translator is likely to encounter. Nevertheless, establishing such a diagnosis is not an easy task. One should decide what factors ought to be taken into consideration, because an in-depth analysis of all possible dimensions is simply beyond the scope of any paper. Hence, for the purposes of the study, the following aspect is considered: the philosophy of language hidden beneath the source text structure. This aspect serves in the paper as a basis for establishing whether Wasowski's version meets basic criteria specified by the translator and whether it renders the 'spirit' of the original version.

The main objective of the paper, as stated above, is to verify whether the latest retranslation of Alice's Adventures in Wonderland (2015) meets the fundamental requirements specified by its translator, that is, whether the version renders the 'spirit' of the source text and whether the attempts which have been made might be referred to as moderate. The first part of the discussion proper focuses on the philosophy behind the linguistic structure of the work in question presented against the backdrop of Hans-Georg Gadamer's ontology of language. The second section discusses the linguistic philosophy in general and stylistic devices in particular in the Polish rendering of the work under investigation. In the third and final part of the paper the author reflects upon the so-called ontological parallelism in translation.

\footnotetext{
3 A moderate translation should be understood as a kind of translation produced within reasonable limits of linguistic creativity on the part of a translator, without making significant changes to the style of the source text.
} 


\section{Lewis Carroll's philosophy of linguistic structure in light of the hermeneutic ontology of language ${ }^{4}$}

Lewis Carroll's work abounds with references to cultural, historical and social figures and regional names, many of which come from English nursery rhymes. Alice's Adventures in Wonderland is full of examples of perverted logic, personification of sayings, as well as striking examples of English humour, the protagonist of which is notably the English language itself (O'Sullivan 2004: 198). Nevertheless, despite a large number of allusions, linguistic riddles, word plays, puns, neologisms, blends, syllogisms and metaphors, it has to be observed that the novel was written in the so-called Queen's (or King's) English, typical of southern parts of England. In other words, in spite of the extensive exploitation of the arbitrary nature of the meanings of English words, a feature which has been closely associated with the author's interest in logic and language, linguistic symbols and signs, letters and anagrams, as well as with the so-called philological ferment of the Victorian era (see Sutherland 1970), Carroll's narration in general and style in particular could be referred to as grammatically correct, clear, coherent and harmonious in terms of syntax and style.

On the surface, then, everything seems to be clear and logical; however, by digging deeper into the linguistic structure of the narration, it becomes obvious that for Carroll it is the matter of linguistics which fills the plot, providing abundant opportunities for the author not only to depict the absurdities of communication among representatives of a wide variety of linguistic communities, but also to touch upon the nature of meaning and language, as well as upon their relationship with the world. As Sutherland (1970: 28) rightly observes:

Language thus became a vehicle for play in a more comprehensive sense than the merely manipulatory. Questions into the nature of meaning, into the character and functions of names, and into the formal structures of language which aid or thwart attempts at communication are exploited for humorous effect simply because they are capable of being so exploited, and because Carroll saw them as such. The whimsical use of language phenomena enabled Carroll to indulge his own delight in playing with language, to puzzle his readers, and - although this was not his paramount intention - to comment indirectly upon the nature of language itself.

Most notably, however, the role which language performs in Alice's Adventures in Wonderland is far more than this. It needs to be pointed out that language in the work in question is not only one of the main themes of the story but also a paramount element of the world depicted, or even the world itself. One could go so far as to say that, hermeneutically speaking, the portrayed reality as presented by Carroll is constituted linguistically; the reality forms the world which is conditioned by the explicit use of language on the surface of the text. Closer observation suggests that language, which here has gained ontosemantic primacy, becomes a meaningful part of Wonderland.

4 In this paper, the hermeneutic ontology of language has been presented as exemplified by Hans-Georg Gadamer's ideas on the linguisticality of human existence. 
Language, as Gadamer once put it, constitutes a universal medium through which understanding of the Other occurs; language is also the place where 'being' resides. Both language and the world, then, are intertwined and closely related. Language cannot exist without the world, and the world cannot exist without language, according to Gadamer.

Similarly, language in Alice's Adventures in Wonderland cannot be treated as a simple tool used to puzzle the readers, because language is the medium through which the world unfolds (Bronk 1988:294). The linguistic unfolding of the world is depicted at the very beginning of the second chapter of the novel, when Alice becomes keenly aware of her own "linguistic metamorphosis": "'Curiouser and curiouser!' cried Alice (she was much surprised, that for the moment she quite forgot how to speak good English) ... " (Carroll 2016: 21). Here, it is worth referring to Gadamer, according to whom "Whoever has language 'has' the world" (Gadamer 2004:499). What does he mean? Firstly, the well-known statement points to the inescapable conclusion that language is where the world presents itself, where it unfolds; secondly, language is the place where man may encounter other beings; thirdly, language is also a place where it is possible for human beings to relate to the world (Gurczyńska-Sady, Sady 2012: 80) as well as to create it. The interpretation holds true with regard to the main differences between the two worlds presented in Carroll's prose, namely, between Wonderland and the 'real'5 world from which Alice came. The statement "Whoever has language 'has' the world" also implies that the kind of language one speaks makes a significant impact on the world which one inhabits. Indeed, the language which lies on the surface of Carroll's novel may be said to represent the so-called 'real' world where human beings live and from which the main protagonist came; however, the language of the underworld, full of instances of perverted logic and nonsense manifested in the use of strange non-existent words and illogical ideas (see Baldick 2008: 232), points to the robust conclusion that utterances produced by the strange creatures living in Wonderland are symbols of another world, possessed by beings who are different from humans in a very distinctive manner. Both human beings and the strange creatures from Wonderland 'have' their own worlds, which are perfectly illustrated by the way they speak and express themselves, as well as by the subject matter behind the words used. Let us refer to a famous example from the chapter A Mad Tea-Party:

The table was a large one, but the three were all crowded together at one corner of it: 'No room! No room!' they cried out when they saw Alice coming. 'There's plenty of room!' said Alice indignantly, and she sat down in a large arm-chair at one end of the table.

'Have some wine,' the March Hare said in an encouraging tone.

Alice looked all round the table, but there was nothing on it but tea. 'I don't see any wine,' she remarked.

'There isn't any,' said the March Hare.

5 The term used here appears in its common meaning, as employed in the so-called pre-philosophical considerations. The distinction between realism and idealism perhaps needs to be borne in mind; however, the notion is definitely beyond the scope of the paper. 
'Then it wasn't very civil of you to offer it,' said Alice angrily.

'It wasn't very civil of you to sit down without being invited,' said the March Hare.

'I didn't know it was your table,' said Alice; 'it's laid for a great many more than three.

'Your hair wants cutting,' said the Hatter. He had been looking at Alice for some time with great curiosity, and this was his first speech.

'You should learn not to make personal remarks,' Alice said with some severity; it's very rude.'

The Hatter opened his eyes very wide on hearing this; but all he said was, 'Why is a raven like a writingdesk?' (Carroll 2016: 82)

Obviously, Alice's bewilderment arises from a misunderstanding between herself and the strange creatures from Wonderland, who do not see anything wrong in what they say. What might be perceived as rude by inhabitants of the so-called 'real' world is certainly deemed normal for the March Hare and for the Hatter. As previously indicated, the misunderstanding clearly results from the fact that Alice and the strange creatures from Wonderland come from radically different worlds, a situation leading to cultural dissonance (see Cara 2017: 110). Alice, governed by the values that she has absorbed and representing the philosophy of Victorian culture, struggles to understand the rules which govern Wonderland discourse (ibid). As Cohan and Shires (2013:5) rightly suggest, "Alice's adventures are, in fact, linguistic misadventures." Wonderland appears strange to Alice, because it seems that she experiences insurmountable difficulties in understanding that here sense is certainly not 'common' and that the odd characters from Wonderland, by constantly challenging the logic of common sense, point to an inseparable link between language and sense (ibid: 9). The challenging of the logic of common sense ${ }^{6}$ has been realized in the most expedient manner in the same chapter through the depiction of the Hatter's and the March Hare's, as well as of Alice's, approach to time:

The March Hare took the watch and looked at it gloomily: then he dipped it into his cup of tea, and looked at it again: but he could think of nothing better to say than his first remark, 'It was the best butter, you know.'

Alice had been looking over his shoulder with some curiosity. 'What a funny watch!' she remarked. 'It tells the day of the month, and doesn't tell what o'clock it is!'

'Why should it?' muttered the Hatter. 'Does your watch tell you what year it is?'

'Of course not,' Alice replied very readily; 'but that's because it stays the same year for such a long time together.'

'Which is just the case with mine,' said the Hatter.

Alice felt dreadfully puzzled. The Hatter's remark seemed to have no sort of meaning in it, and yet it was certainly English. 'I don't quite understand you,' she said, as politely as she could. (Carroll 2016: 84)

6 It seems that the strange creatures are cognizant of the fact that they are challenging sense as is widely accepted in Alice's world (the real world). I am grateful to one of the reviewers for this valuable comment. 
If one accepts that, as Gadamer put it, the world exists only to the extent in which it is mediated by language, then the obvious conclusion is that Wonderland unfolds through linguistic and (il) logical means, as used by its inhabitants. Therefore, the whole place exists as long as puns, riddles, word plays, metaphors, neologisms, cases of perverted logic, etc. are created. The nature of any world relies on interpretation, which in turn is determined by a particular use of linguistic conventions, because language is an all-embracing explanation, and/or interpretation, of the world. Gadamer (1972: 239) also argues that when a human being enters the world, he/she encounters a concrete world conditioned by the language which is used there, as well as by the way the world is presented in language.

The most important finding for this study-as derived from what the author of Wahrheit und Methode claims-is that Alice also comes across a world which has been determined linguistically. Because Wonderland unfolds in language, in Alice's case the so-called linguistic experience of the world encompasses all being that has ever existed and will exist. Thus it is not Wonderland that constitutes the object of language, but it is the object of human cognition (of Alice's cognition) which is being embraced by a wide horizon of language (see Gadamer 1965: 426). That is why, putting aside the strange events taking place, it is possible both for Alice and for readers to recognize the eccentricity of Wonderland.

In Carroll's novel, language serves as a demarcating line between the two worlds. From the narrator's perspective it seems that everything is clear and coherent; however, a significant change occurs the moment the odd creatures from Wonderland start producing utterances. This also accords with the main tenets of Gadamer's ontology of language, where it is shown that language cannot exist without a world, and, in a similar vein, a world cannot exist without language. In other words, it is language which influences the world, and it is the world which influences language. What is crucial at this point is to what language, in light of Gadamerian hermeneutic ontology, pertains. It seems fair to say that "language withdraws in order to serve up its message, in order to communicate ... language is mostly silent about itself" (Schmidt 2015:345). Language, then, is not so much about particular words or phrases which are employed in order to express any sense; rather, language is a being which constitutes and forms the so-called hermeneutic experience connected with meeting the Other. Once more, the emphasis should be placed on the way Carroll wrote, i.e. by means of a very standard form of the English language, in a clear, coherent and harmonious style, even when what he referred to was certainly illogical in terms of the rules with which Alice, as a little Victorian girl, was acquainted. Let us refer to a famous episode from the chapter Pig and Pepper:

Alice went timidly up to the door, and knocked.

'There's no sort of use in knocking,' said the Footman, 'and that for two reasons. First, because I'm on the same side of the door as you are; secondly, because they're making such a noise inside, no one could possibly hear you...

'Please, then,' said Alice,' how am I to get in?'

'There might be some sense in your knocking,' the Footman went on without attending to her, 'if we had 
the door between us. For instance, if you were inside, you might knock, and I could let you out, you know.' (Carroll 2016: 69)

The above episodes point to the firm conclusion that, contrary to what is commonly held in literature, it is not so much the language itself manifested in particular words or expressions but rather what is hidden behind those words and expressions which performs a fundamental role in the work under investigation. Although Wonderland-as mentioned-unfolds in language, the language shall be understood as logos, mediating between man and the surrounding reality, and certainly not as an instrumental multitude of linguistic signs (see Bronk 1988: 291). Following Hans-Georg Gadamer's idea about the linguistic functioning of a human being in the world, one can conclude that because all being which could be understood is language, then Wonderland itself can be referred to as some sort of language. It is the language that denotes a myriad of potent symbols extolling the symbiotic relationship between human beings and the surrounding reality in all its facets, including manifold cases of perverted logic. These cases are typical not only of such fictitious worlds as Wonderland but, first and foremost, of the world which is so often depicted as 'real.' Lewis Carroll-as it seems-in his work created two distinct worlds, and yet the worlds overlap each other with regard to language. Despite the daunting challenges posed by the odd creatures from Wonderland with relation to logic and so-called 'common sense', the language, to a large extent, is clear and perfectly understandable, and sentences are logically structured in terms of grammar. As a consequence, lexical and syntactic means remain, at least to some extent, hidden and dormant. Kozak (2000: 171) rightly observes that Wonderland had been created in a quasi-fantastic convention, meaning that the whole situation is seemingly possible to accept in a fantastic convention, and that this is only a reflection which reveals the genesis of realism in the world depicted in the novel (as opposed to a quasi-realistic convention), and that the metaphor, being a basis for the development of the narration, is made real and transformed into a metamorphosis which is, however, not fairy-tale-like, because not all connections with a realistic convention were broken (ibid: 172). It should be noted that the language in this novel perfectly illustrates the idea. The non-conventional use of words, as well as cases of perverted logic and nonsense (manifested not only in language but also in the behaviour of the strange creatures), among other elements, clearly point to a fantastic convention; however, firstly, the fact that the creatures use the same language as human beings do, and, secondly, that they produce utterances according to the syntactic and pragmatic rules as agreed in the so-called 'real' world from which the main protagonist came, explicitly indicate the extent to which the real world permeates Wonderland and its linguistic conventions. Despite the use of manifold word plays, puns, riddles or neologisms, for the strange creatures which Alice encounter, Wonderland is 'real' in the sense of their feeling of belonging and their familiarity with their surroundings. Therefore, the whole narration being conducted in language typical of the educated English represents the abovementioned realistic genesis of the plot; however, the linguistic interpolations as manifested in the creatures' extraordinary ways of expressing themselves stand for the inversions of the realistic convention, thus leading to 
the creation of a quasi-fantastic dimension where, linguistically speaking, everything is possible, ${ }^{7}$ even for no valid reason at all, as in the famous scene when Alice listens to the Dormouse's story:

'They were learning to draw,' the Dormouse went on, yawning and rubbing its eyes, for it was getting very sleepy; 'and they drew all manner of things - everything that begins with an $\mathrm{M}-{ }^{\prime}$ 'Why with an M?' said Alice.

'Why not?' said the March Hare.

Alice was silent. (Carroll 2016: 90)

Interestingly enough, the main protagonist of the novel often becomes painfully aware of her linguistic adapting to Wonderland, for instance in the second chapter, in which she says: “. . O dear, what nonsense I'm talking!" (Carroll 2016: 22). She also quickly takes cognizance of the striking differences between her world and Wonderland:

'It was much pleasanter at home,' thought poor Alice, 'when one wasn't always growing larger and smaller, and being ordered about by mice and rabbits. I almost wish I hadn't gone down that rabbit-hole - and yet - and yet - it's rather curious, you know, this sort of life! I do wonder what can have happened to me! When I used to read fairy-tales, I fancied that kind of thing never happened, and now here I am in the middle of one! There ought to be a book written about me, that there ought! And when I grow up, I'll write one - but I'm grown up now,' she added in a sorrowful tone; 'at least there's no room to grow up any more here.' (Carroll 2016: 44)

Owing to this state of utter bewilderment, Alice encounters considerable difficulties in finding proper words to express herself, as in the scene with the Caterpillar, when she replies politely: “'I can't explain myself, I'm afraid, sir,' said Alice, 'because I'm not myself, you see." (Carroll 2016: 55), as if finally accepting that Wonderland has been constituted linguistically and everything there has its own linguo-(il)logical structure.

Crucially, both language and the world depicted in Alice's Adventures in Wonderland are of a speculative character. For language does not possess an innate system of logic; it simply expresses the way people speak. What is expressed, though, does not acquire a second existence, but it presents its own way of being (Gadamer 1965: 450). “The speculative character of language is simply the notion that every determination of meaning is dynamically related to a whole of meaning, a whole that is infinitely beyond itself" (Risser: 2010: 14). As Davey (2016: 244) rightly highlights, "the speculative capacity of words therefore refers to their power to insinuate an infinite horizon of possible meaning. When operating speculatively, the word reveals our existence in the primordial horizons of linguisticality, horizons which transcend each and every one of us." Words, then, should be considered to be separate entities from what is hidden beyond their structure. It would

7 It also accords with Kozak's idea about “Alice’s semantic adventures” (see Kozak 2000: 172). 
not be too gross a generalization to say that a word is one thing and what it expresses is another. Obviously, the word and its content, forming two distinct dimensions of a hermeneutic experience, are not juxtaposed against each other but rather closely interrelated. Concerned not so much with the internal structure of words themselves as with what is conveyed through them, Carroll, by creating Wonderland, offers startlingly astute observations of how superficial the language and linguistic means employed by man are, and how very thin the line dividing sense and nonsense is. To this end, perhaps, Carroll chose to 'hide', at least to some extent, the linguistic reality of Wonderland, with its numerous word plays, riddles, neologisms and cases of perverted logic and nonsense, under the cloak of 'standard and correct' English, presumably to demonstrate how the two worlds in the novel under investigation are distinct, and yet how they mutually overlap each other, their uniqueness and separateness so often dissipated. Let us now consider whether, and to what extent, the philosophical structure presented above has been rendered in the latest retranslation of this novel.

\section{Language $^{8}$ in Grzegorz Wasowski's translation - results of the analysis}

It is not a word-for-word translation-unless it is possible-but rather an idea-for-idea rendering that should be followed, according to Wasowski (2015: 160). As the translator claims, he would reflect upon one word for weeks, and the moment he finally settles for a word that is less than ideal signifies that a given word is not rendered with great panache (161). Wasowski employed the following translation strategies: adding, deleting and replacing (162-173), primarily with the aim of entertaining his readership. This aim - it seems-has been realized through disrupting the harmony of the style, so evident in the source text, on the following three dimensions: simplicity, concision and homogeneity (based on Markowski 2005: 120-1). These dimensions were chosen because, as indicated, this novel was written in a simple, concise and relatively homogeneous style; hence, simplicity, concision and relative homogeneity succinctly characterize the style of the source text.

Although a literary work, generally speaking, should not be analysed in terms of stylistic functionality (see Markowski 2005: 119), it has to be underlined that in order to verify whether the requirements as specified by Wasowski have been fulfilled and to what extent the philosophy behind the linguistic structure in the source text has been reflected in the Polish retranslation, one has to follow certain criteria, in particular when comparing the source and target texts within the field of translation. Owing to the fact that, as mentioned, Alice's Adventures in Wonderland was written

\footnotetext{
8 The discussion of the notion language is definitely beyond the scope of this paper; therefore, the stress here is laid solely on the stylistic dimension as presented in the target text. Besides, as Jin Di (2014: 148) rightly suggests, "Style has been very much neglected in translation studies because of its deceptive simplicity. Yet it is the subtlest part of literary writing and in any translation certainly one of the most outstanding factors that contribute to the effect the translation produces on its readers". It also goes without saying that a sensitive translator should make all reasonable efforts to analyse the style of the source text.
} 
in the standard Southern British English spoken in educated circles (for more on writing in Victorian fiction see Chapman 2014:16), the stress will here be laid on the way the stylistic component has been rendered in the target version. On the basis of the remarks made about style, provisional conclusions regarding the extent to which the philosophy behind the linguistic structure of the source text has been rendered in the target version will be drawn.

The abovementioned disruption is realized, first and foremost, through disturbing the first dimension, namely, simplicity of style. The simplicity of style comprises a selection of the most natural lexical elements for a given text, the use of simple grammatical structures, as well as the avoidance of such linguistic means which are employed solely for so-called 'ornamental' purposes (Markowski 2005: 120-1). A systematic analysis of the target text has shown that Wasowski used a myriad of such means, which might be referred to as some forms of 'pretence.' They are manifested, among others, in the use of so-called pseudo-elegant vocabulary:

\section{Example 1.}

(Alicja nie miała bladego pojęcia, co kryje się pod określeniami "szerokość" $i$ "długość geograficzna”, nie potrafiła sobie jednakże odmówić wypowiedzenia słów tak, jak mniemała, uroczo podniosłych).

(Carroll 2015: 14)
(Alice had no idea what Latitude was, or Longitude either, but thought they were nice grand words to say.) (Carroll 2016: 13).

In addition to employing a pseudo-elegant style, the translator used pseudo-scientific lexis which oftentimes alternates with lexical items such as those exemplified above. An illustration is provided in Example 2.

\section{Example 2.}

I rzeczywiście tak było: mierzyła teraz tylko dziesięć cali i jej twarz rozjaśniła się na myśl, iż dysponuje wreszcie odpowiednim wzrostem, aby móc przejść przez drzwiczki do najśliczniejszego ogrodu.

(Carroll 2015: 18)
And so it was indeed: she was now only ten inches high, and her face brightened up at the thought that she was now the right size for going through the little door into that lovely garden.

(Carroll 2016: 18).

Finally, the disruption of the simplicity of style is also manifested in the extensive use of trendy, overused words (such as 'iż,' 'wszakże,' 'bynajmniej, 'albowiem,' etc. '), which make the style of the target version a rather pretentious and inflated one; the so-called figurative suitcases, or portmanteau (such as 'srogostro,' 'głupiudno,' 'całkompletnie'), employed in those fragments in which Car-

9 The English counterparts could be as follows: that, nevertheless, nowise, since; however, they by no means mirror the semantic and pragmatic dimension of the Polish words in question. 
roll used very standard and neutral lexis; as well as a huge number of archaisms which can easily be identified even within the very first sentence of the narration:

Example 3.

Alicję ogarniało narastające wciąż znużenie, wynikłe z przesiadywania na skarpie obok siostry i mitrężenia czasu na próżniactwie.

(Carroll 2015: 13)
Alice was beginning to get very tired of sitting by her sister on the bank, and of having nothing to do...

(Carroll 2016: 11)

The disruption of the harmony of style also occurs in the dimension of concision. It seems that Wasowski purposefully added a large number of lexical items which are, however, wholly unnecessary, making the story too wordy and lengthy and, above all, changing the meaning dimension of the narration (for more on semantics in translation see Stolze 2011: 116-124):

\section{Example 4.}

Alicję ogarniało narastajq̨ce wciq̨ż znużenie, wynikłe z przesiadywania na skarpie obok siostry i mitrężenia czasu na próżniactwie. Raz czy też może dwa zajrzała do czytanej przez siostrę ksiqż̇ki, ale nie dojrzała w niej ni obrazków, ni dialogów. „Co i komu może przyjść z książki bez obrazków i dialogów?" - pomyślała i zajęła się rozważaniem (na tyle, na ile w ogóle było to możliwe, jako że spiekota dnia zanurzała w senność i ja, i jej rozum) zagadnienia: czy wyrzeczenie się pozycji siedzqcej na rzecz stojącej, a następnie mozół zrodzony z własnoręcznego nazrywania stokrotek zdoła sobie powetować, choćby w części, przyjemnościq, którq (w końcu nie od razu) czerpać będzie z uplecenia (ze stokrotek tychże) wianka, gdy nagle przebiegł tuż koło niej Biały Królik o różowych ślepkach.

(Carroll 2015: 13)
Alice was beginning to get very tired of sitting by her sister on the bank, and of having nothing to do: once or twice she had peeped into the book her sister was reading, but it had no pictures or conversations in it, 'and what is the use of a book,' thought Alice, 'without pictures or conversation?' So she was considering in her own mind (as well as she could, for the hot day made her feel very sleepy and stupid), whether the pleasure of making a daisy-chain would be worth the trouble of getting up and picking the daisies, when suddenly a White Rabbit with pink eyes ran close by her.

(Carroll 2016: 11-12)

The third disturbed dimension of the style is its relative heterogeneity. In the target text the disruption is manifested, first and foremost, in a style alternating between colloquial and bookish. Such alternations, it seems, lead to potential confusion in the readership because of a radical change in the perception of Alice: in some scenes she acts as a sentimental little girl who uses vocabulary typical of the very beginning of the $20^{\text {th }}$ century, so reminiscent of Anne of Green Gables in Bernsteinowa's translation, while at other times she employs linguistic means indicative of youth slang: 


\section{Example 5.}

Zaraz, zaraz, rozsądniej chyba będzie trzymać

z nimi sztamę - zmitygowała się raptem Alicja bo w przeciwnym razie mogą nie zechcieć udać się tam, dokq̨d ja się udać zechcę.

(Carroll 2015: 23)

"Dina zapewne okrutnie będzie tęsknić za mną dziś wieczorem - jak mogłam nie wziąć tego pod uwagę!" (Carroll 2015: 15)

"Wydostańmy się tedy na brzeg, a zapoznam cię z ma przeszłościq, i nie będziesz się już dziwić, dlaczego aż tak nie trawię psów i kotów".

(Carroll 2015: 29)
I shall be a great deal too far off to trouble myself about you: you must manage the best way you can; - but I must be kind to them,' thought Alice, 'or perhaps they won't walk the way I want to go!

(Carroll 2016: 22)

'Dinah'll miss me very much to-night, I should think!'

(Carroll 2016: 14)

'Let us get to the shore, and then I'Il tell you my history, and you'll understand why it is I hate cats and dogs.' (Carroll 2016: 31)

The examples provided above convincingly demonstrate that the philosophy of language as presented in the second part of this paper has not been rendered in the translation produced by Wasowski (2015), in particular with regard to the 'speculative' nature of language. Following Sołtysiak's arguments (2004: 95-98), one can claim that because Wonderland is constituted linguistically, language is the medium through which the reality unfolds; however, the medium is, to some degree, 'invisible', and thus it hides beneath that which it reflects itself. The relative invisibility of the linguistic medium is, paradoxically, pronounced in the source text where Carroll employs so-called standard English and writes in a clear and homogeneous style. By 'hiding' language, which in the target version is manifested in the disruption of the harmony of style, Wasowski brings the strange reality of Wonderland out, making it possible for readers to differentiate between the two worlds depicted in the novel. At this point, however, one could assert that the 'speculative' nature of language also applies to how the reality is interpreted by a reader, or by an interpreter and a translator. On the other hand, though, the way things are presented in language is not an "outer" activity but the unfolding of the 'thing' itself (ibid: 95). Wonderland and language, then, form a speculative unity, which means that words do not reflect a given being so that it is possible to contain the being in the words, but they assume a particular attitude towards the whole being, allowing it to speak (ibid: 96). Thus, words in Wonderland might be considered to function only because of what is conveyed through them. They exist only to dissolve in what has been said (see Gadamer 1965: 450). In the target text, though, it seems that words in Wonderland do not melt away in order to depict the fictitious world, but they gain a second existence. Wonderland in Wasowski's interpretation does not constitute a speculative unity of language and portrayed reality, and this leads, as a result, to the differentiation between the world depicted and the linguistic means employed by the translator. Words and phrases used in the target text do not reveal Carroll's Wonderland but rather a totally different world: a world of linguistic signs and infinite possibilities of language. In other words, Wasowski, in a way, failed "to capture the said within the context of unsaid" (Lawn, Keane 2011:136). For Carroll, by reducing the 'ornamental' aspects of language, he created a significant opportunity to "give meanings to the chain of meanings in the said" (ibid), 
or, put differently, to generate an infinity of meanings. Wasowski, on the other hand, by exploiting the said to a greater extent than Carroll did, caused the gradual disappearance of the unsaid.

Language in the source and target texts performs markedly different roles. While in the source text language should rather be referred to as a specific set of senses (Bronk 1988: 315) through which contents are transmitted (also about the language itself), in the target text it assumes a more instrumental role and becomes the means by which its mere 'creative' possibilities are exploited. A provisional conclusion, then, is that Wasowski did not render the capacity of language to go beyond itself. In the target text, language does not exist to convey what is said through it, but rather presents itself as the most important component of the whole narration, as if it were a private individual language of the translator. It is not so much Wonderland but rather the translator that unfolds himself throughout the rendering-all the more so when the style of the translator is analysed, for example, on the basis of his afterword, in which all three dimensions of the disruption of the harmony of style can be readily identified. While in the source text language starkly and gradually reveals a quasi-fantastic reality in which the main protagonist finds herself, in the target text it is the language itself that is revealed, with all its possibilities and shortcomings, and of which almost a caricature is made.

\section{Final remarks}

This essay has discussed the extent to which the philosophical structure of language as presented in Alice's Adventures in Wonderland has been rendered in the latest Polish retranslation (Wasowski 2015). The main goal of this paper was also to assess whether Wasowski has managed to render the so-called English 'spirit' of the text and whether the actions undertaken have been conducted moderately, within particular linguistic limits, as the translator intended before he proceeded with the translation. Returning to the questions posed at the beginning of this study, it is now possible to state that there are two utterly distinctive ontologies of language presented in the source and target texts. Despite the fact that Wasowski intended to render the English 'spirit' of the source text in the translation by means of the richness of the Polish language, it seems that his perception of the text was too narrow to successfully complete the task. In his afterword, Wasowski precisely explained the motives behind his decision to adopt a particular translation strategy, referring to his own rendering as an 'unfaithful translation.' While one, generally speaking, agrees with the translator's intention to translate the idea of a text and not its words, there is, however, a big controversy surrounding Wasowski's postulate that the 'spirit' of the source text should be rendered, among others, by means of a wide variety of Polish lexis (2015: 161). While a large number of excellent translation solutions have been supplied by Wasowski, at the same time it has to be underlined that he did not manage to show great moderation in his attempts, alternating between various incompatible styles and distorting the harmony which accurately defines the source text. Wasowski's apparent disregard for these principles should be altogether surprising given the fact that he himself claimed how important it is for a translator to stay within particular bounds of practice so that it is the author of the source text who plays the most decisive role in the whole process. 
In a similar vein, one can hardly agree with Wasowski's statement that the richness of one's own imagination should keep pace with the richness of a language, with a picture frame and a picture being equally important (2015: 161). While it is undoubtedly true that both form/sense or content/ style (see Hatim, Munday 2004: 10) should be carefully treated by a translator in any translation process, the question which arises here is whether, and to what extent, the form contributes to sense (ibid) in Alice's Adventures in Wonderland. If one accepts that in this novel form and sense (or content/style) are, indeed, equally important (see considerations above regarding a quasi-fantastic convention and its realistic genesis), then Wasowski, despite aiming for such a unity, did not manage to achieve it. Paraphrasing Stolze (2003: 296), it might be concluded that Wasowski unnecessarily prioritized one component, i.e. a wide variety of Polish vocabulary, thus leading to the narrowing of the so-called "truth of the text." While it is not possible to encompass in a translation all potential perspectives defining a source text, the crucial point is to retain overall responsibility and remember that a translator's task is, first and foremost, to act as a mediator and co-author rather than a second author (see Stolze 2003: 207-224). Finally, it seems that the target text is lacking in a necessary "oversummativity" and "multiperspectivity", a set of manifold narrative perspectives which have to overlap each other (for more see Paepcke 1986a). In the case of this novel, the perspectives might include: a quasi-fantastic convention with a realistic genesis, ontology of language manifested in a wide array of relationships between man and language, stylistic conventions, ideological factors (the Victorian period and the issues of education) or ontological parallelism, to mention but a few.

Let us concentrate on the final element among those mentioned above. While the notion of equivalence has fulfilled a prominent role in translation theory, all too often it has been referred to as some sort of "equality" between two texts and closely entwined with an almost mathematical sameness. Wasowski's inclination towards producing an unfaithful translation, however, does not allow us to derive definite conclusions regarding the extent to which the two texts are equivalent. Besides, what seems interesting to note is that the discourse of sameness does not make sense in the life-world (Lebenswelt), because the relationship between text and translation is fiendishly complicated. What is more, the basis of the relationship is not equivalence but "parallelism in an opposition" (Paepcke 1986b; 144-149, after Bukowski 2012: 25). Hence, it seems reasonable to consider yet another type of relationship between the source and target texts, one which is not subject to the discourse of identity, namely, ontological parallelism.

Ontological parallelism should be understood as the use of such linguistic means, including syntactic structures, to balance the ideas contained within the source and target texts, with regard to the being(s) existing in the world depicted. In the case of the novel under question, the being filling the principal role is Wonderland, and it is this component that should capture the translator's meticulous attention. Wonderland, as a place of fantastic provenance, is immersed in conventions typical of the real world (Kozak 2000), the two dimensions aptly fitting each other. More significantly, Wonderland, as yet another type of language in itself, is parallel to the world from which Alice came. It acts as a mirror of certain conventions of the real world, in particular of linguistic 
ones, presenting and disclosing rather than reflecting or representing (see Lawn, Keane 2011: 136). The meanings which are mirrored, however, are "never entirely uttered" (see Grondin 1995: 13). To recapitulate, Wasowski, by distorting the harmony of style and exploiting to a great degree the semantic potential of the Polish language, uttered, perhaps, too much, precluding, or limiting, the immense possibilities of a widely understood interpretation. In adhering to the uttered words themselves, the translator did not manage to reach "the dimension of the unsaid" (ibid). As a result, he managed neither to achieve ontological parallelism nor to render the 'spirit' of the English version of the novel, creating a vastly different world from the one which Carroll invented; a world in which comic effects predominate over the unfathomable mystery of the linguistic functioning of a human being.

\section{References}

\section{Primary sources}

Carroll, Lewis. 2015. Perypetie Alicji na Czarytorium (transl. by G. Wasowski). Warszawa: Wydawnictwo Wasowscy.

Carroll, Lewis. 2016 (originally published in 1865). Alice's Adventures in Wonderland. London: Vintage.

\section{Secondary sources}

Baldick, Chris. 2008. Oxford Dictionary of Literary Terms. Oxford: Oxford University Press.

Bronk, Andrzej. 1988. Rozumienie, dzieje, język. Filozoficzna hermeneutyka H.-G. Gadamera. Lublin: Redakcja Wydawnictwo Katolickiego Uniwersytetu Lubelskiego.

Bukowski, Piotr. 2012. Dydaktyczne aspekty hermeneutycznej teorii przekładu. In: Maria Piotrowska \& Joanna Dybiec-Gajer (eds.), Przekład - teorie, terminy, terminologia, Język a komunikacja 30, 17-28. Kraków: Wydawnictwo Tertium.

Cara, Coral. 2017. Alice in Wonderland. Opening the Doors to Inclusive Practices of Teaching and Learning for All Students. In: Vicky Plows \& Ben Whitburn (eds.), Inclusive Education: Making Sense of Everyday Practice, 107-125. Rotterdam/Boston/Taipei: Sense Publishers.

Chapman, Raymond. 2014. Forms of Speech in Victorian Fiction. London/New York: Routledge.

Cohan, Steven and Linda M. Shires. 2013. Telling Stories: The Theoretical Analysis of Narrative Fiction. London/New York: Routledge.

Cohen, Morton N. and Anita Gandolfo. 1987. Lewis Carroll and the House of Macmillan. Cambridge: Cambridge University Press.

Collingwood, Stuart Dodgson. 2008. The Life and Letters of Lewis Carroll. London: Forgotten Books.

Davey, Nicolas. 2016. Word, Image, and Concept. In: Niall Keane \& Chris Lawn (eds.), The Blackwell Companion to Hermeneutics, 242-247. Chichester: John Wiley \& Sons, Inc.

Di, Jin. 2014. Literary Translation: Quest for Artistic Integrity. London/New York: Routledge.

Gadamer, Hans-Georg. 1965. Wahrheit und Methode. Tübingen: J.C.B. Mohr. 
Gadamer, Hans-Georg. 1972. Kleine Schriften III. Idee und Sprache. Platon. Husserl. Heidegger. Tübingen: J.C.B. Mohr.

Gadamer, Hans-Georg. 2004. Truth and Method. New York: Continuum Publishing Group.

Grondin, Jean. 1995. Sources of Hermeneutics. Albany: State University of New York Press.

Gurczyńska-Sady, Katarzyna and Wojciech Sady. 2012. Wielcy filozofowie wspótczesności. Kęty: Firma Dystrybucyjna ANTYK Piotr Derewiecki.

Hatim, Basil and Jeremy Munday. 2004. Translation: An Advanced Resource Book. London/New York: Routledge.

Jaques, Zoe and Eugene Giddens. 2016. Alice's Adventures in Wonderland and Through the Looking Glass: A Publishing History. London/New York: Routledge.

Kozak, Jolanta. 2000. Alicja pod podszewką języka. Teksty Drugie 5 (64). 167-178.

Lawn, Chris and Niall Keane (eds.). 2011. The Gadamer Dictionary. London/New York: Continnum International Publishing Group.

Markowski, Andrzej. 2005. Kultura języka polskiego: Teoria. Zagadnienia leksykalne. Warszawa: Wydawnictwa Naukowe PWN.

O’Sullivan, Emer. 2004. Comparative Children's Literature. In: Peter Hunt (ed.), International Companion Encyclopedia of Children's Literature, 191-202. London/New York: Routledge.

Paepcke, Fritz. 1986a. Im Übersetzer leben. Übersetzen und Textvergleich. Tübingen: Narr.

Paepcke, Fritz. 1986b. Die Illusion der Äquivalenz. Übersetzen zwischen Unschärfe und Komplementarität. In: Elvira Groezinger \& Andreas Lawaty (eds.), Suche die Meinung. Karl Dedecius, dem Übersetzer und Mittler zum 65. Geburtstag, 116-151. Wiesbaden: Harassowitz.

Pym, Anthony. 1998. Method in Translation History. Manchester: St. Jerome Publishing.

Risser, James. 2010. Gadamer's Hidden Doctrine: The Simplicity and Humility of Philosophy. In: Jeff Malpas \& Santiago Zabala (eds.), Consequences of Hermeneutics: Fifty Years After Gadamer's Truth and Method, 5-24. Evanston: Northwestern University Press.

Schmidt, Dennis J. 2015. Text and Translation. In: Jeff Malpas \& Hans-Helmuth Gander (eds.), The Routledge Companion to Hermeneutics, 345-353. London/New York: Routledge.

Sołtysiak, Marek. 2004. Rozumienie i tradycja w hermeneutyce filozoficznej Hansa-Georga Gadamera. Kraków: Wydawnictwo Naukowe Papieskiej Akademii Teologicznej w Krakowie.

Stolze, Radegundis. 2003. Hermeneutik und Translation. Tübingen: Gunter Narr Verlag.

Stolze, Radegundis. 2011. The Translator's Approach - Introduction to Translational Hermeneutics: Theory and Examples from Practice. Berlin: Frank \& Timme.

Sutherland, Robert D. 1970. Language and Lewis Carroll. The Hague/Paris: Mouton \& Co. N. V. Venuti, Lawrence. 2013. Translation Changes Everything: Theory and Practice. London/New York: Routledge. 